\title{
Orta Asya Ülkelerinde Yaş Meyve ve Sebze Sektörünün Dış Ticaret Yapısının Analizi
}

Güçgeldi BASHIMOV ${ }^{1}$

\begin{abstract}
Özet
Bu çalışmanın amacı, Orta Asya (Türkmenistan, Özbekistan, Kazakistan, Kırgızistan ve Tacikistan) ülkelerinin yaş meyve ve sebze sektörünün dış ticaret yapısını analiz etmektir. Çalışmada yaş meyve ve sebze sektörünün rekabetçilik düzeyi ve endüstri-içi ticaret yapısı analiz edilmiştir. Çalışma 20022015 dönemini kapsamakta olup, çalışmada kullanılan veriler Uluslararası Ticaret Merkezi'nin veri tabanından derlenmiştir. Analiz aşamasında Açıklanmış Karşılaştırmalı Üstünlükler İndeksi, Net Ticaret İndeksi ve Grubel-Lloyd İndeksi kullanılmıştır. Araştırma bulgularına göre Özbekistan, Kırgızistan ve Tacikistan yaş meyve ve sebze sektöründe rekabet gücüne sahiptir. Türkmenistan ve Kazakistan'ın yaş meyve ve sebze sektöründe rekabet gücünün düşük olduğu belirlenmiştir. Ayrıca, Orta Asya ülkelerinde yaş meyve ve sebze sektöründe endüstri-içi ticaret seviyesinin düşük olduğu belirlenmiştir.
\end{abstract}

Anahtar Kelimeler: Dış ticaret, Rekabet gücü, Orta Asya

\section{Analysis of Foreign Trade Structure of Fresh Fruit and Vegetable Sector in Central Asian Countries}

\begin{abstract}
The objective of this study is to analyze the foreign trade structure of the fresh fruit and vegetaable sector of Central Asian (Turkmenistan, Uzbekistan, Kazakhstan, Kyrgyzstan and Tajikistan) countries. In study, the competitiveness and intra-industry trade structure of the fresh fruit and vegetable sector were analyzed. The study used International Trade Centre statistical data for the period 2002-2015. In this study, used Revealed Comparative Advantage Index, Net Trade Index and Grubel-Lloyd Index. A study found that Uzbekistan, Kyrgyzstan and Tajikistan have competitive power in fresh fruit and vegetable sector. It was found that the competitive power is low in the fresh fruit and vegetable sector in Turkmenistan and Kazakhstan. Also, it was found that the level of intraindustry trade is low in the fresh fruit and vegetable sector in Central Asian countries.
\end{abstract}

Keywords: Foreign trade, Competitiveness, Central Asia

\section{Giriş}

Tarım, temel gıda maddeleri üretimini garanti ederek, nüfusun önemli bir kısmına istihdam imkânı yaratarak, sınai sektöre emek, ara malı ve piyasa sağlayarak, ekonomiye döviz kazandırarak ve iç piyasanın genişlemesine yol açarak ekonomik gelişme sürecine katkıda bulunmaktadır. Ayrıca çoğu gelişmekte olan ülkede kırsal alanlarda yaşayanların geçimlerini sağladıkları temel sektör tarımdır (Doğan, 2009: 22). Tarım sektörü çok farklı açılardan toplumu etkilemektedir. Tarımın etkileri ve katkıları genel olarak şu beş başlık altında toplanabilmektedir: ekonomik kalkınma, yoksulluğun azaltılması, cinsiyet eşitliği sağlama, gıda güvenliği ve çevresel sürdürülebilirlik (Özertan, 2013: 12).

Tarım sektörü, ülkelerin gelişmişlik düzeyi ne olursa olsun, tüm ülkelerin ekonomik hayatlarında önemli bir yere sahiptir. Tarım sektörü, günümüze kadar

\footnotetext{
${ }^{1}$ Ömer Halisdemir Üniversitesi Sosyal Bilimler Enstitüsü, İşletme Anabilim Dalı, guyc55@gmail.com
} 
Yalova Sosyal Bilimler Dergisi

ülkelerin ekonomik ve sosyal hayatında çok önemli görevler üstlenmiştir (Doğan ve ark., 2015: 30). Tarım sektörünün özellikle gelişmekte olan ülkelerde ekonomik büyümenin sağlanmasında temel belirleyici güç olduğuna dair iktisat tarihi bize bolca kanıtlar sunmaktadır (Agwu ve ark., 2014: 158). Günümüzde tarım sektörü, gelişmiş ve gelişmekte olan her bir ülke için vazgeçilmez olup, uzun vadeli planlarda önemle yer verilen bir sektördür (Kaya ve Erdoğan Aktan, 2011: 262).

Tarımsal faaliyetler ekonomiye sağladığı katkılardan dolayı diğer gelişmekte olan ülkelerde olduğu gibi Orta Asya ekonomileri açısından da çok büyük bir önem arz etmektedir. Tarım sektörü milli gelir, istihdam ve dış ticaret açısından Orta Asya ekonomilerine önemli katkılar sağlamaktadır. Örneğin, tarım sektörünün GSYIH'daki payı Kırgızistan'da \%32, Tacikistan'da \%30 ve Özbekistan'da ise \%24'dür (Peyrouse, 2009: 5). Bununla birlikte Orta Asya ülkeleri tarım ürünleri satışından önemli düzeyde döviz girdisi elde etmektedir. Dünya Ticaret Merkezi'nin istatistiki verilerine göre tarım ürünlerinin toplam ihracattaki payı Özbekistan ve Tacikistan'da \%20 seviyelerindedir. Bu yönüyle tarım sektörü Orta Asya ekonomileri açısından önemli sektörlerin başında gelmektedir.

$\mathrm{Bu}$ çalışmanın temel amacı Orta Asya ülkelerinin (Türkmenistan, Özbekistan, Kazakistan, Kırgızistan ve Tacikistan) yaş meyve ve sebze sektörünün dış ticaret yapısını analiz etmektir. Çalışmada ilk olarak sektörün rekabet gücü ardından da endüstri-içi ticaret yapısı incelenmiştir. Rekabet gücünün belirlenmesinde Bela Balassa tarafından geliş̧irilen açıklanmış karşılaştırmalı üstünlükler ve net ihracat indeksi kullanılmıştır. Endüstri-içi ticaretin ölçümünde ise Grubel-Lloyd indeksi kullanılmıştır. Çalışmada 2002-2015 dönemi analiz edilmiş olup, HS 2 haneli sınıflandırma düzeyi kullanılmıştır.

\section{Rekabet Gücü Kavramı}

Günümüzde uluslararası ihracat pazarlarını ele geçirebilmek, bu pazarlarda tutunabilmek veya pazar payını artırabilmek için ülkeler arasında amansız bir yarış vardır. Bu yarışta başarılı olabilmenin temel koşulu ise yüksek bir rekabet gücüne sahip olmaktır (Seyidoğlu, 2015: 575). Bu yüzden, gerek yerli, gerekse yabancı literatürde son yıllarda rekabet ile ilgili yapılan araştırmalar oldukça önem kazanmış bulunmaktadır (Saraçoğlu ve Köse, 2000: 1).

Rekabet kavramı iktisat düşüncesinde her zaman merkezi bir öneme sahip olmuştur. İktisat kuramının temel taşlarından biri olan ve birçok iktisadi teorinin özünü oluşturan rekabet kavramının tanımlanması üzerinde iktisatçılar kesin bir fikir birliğine varamamışlardır (Kırankabeş, 2006: 232). Kökeni karşılaştırmalı üstünlükler teorisine dayanan uluslararası rekabet gücü çok genel anlamda, "bir ülkenin ürettiği bir ürünü dünya fiyatlarından dünya piyasalarında satabilme, uluslararası pazarda etkili bir ihracat payına sahip olabilme ve bu konumunu devam ettirebilme gücü” olarak tanımlanabilmektedir (Saraçoğlu ve Köse, 2000: 1). Bir başka ifadeye göre rekabet gücü, bir ülkenin ürettiği mallarda diğer ülkelerin malları ile fiyat, kalite, tasarım, güvenilirlik ve zamanında teslim gibi unsurlarda yarışabilir düzeyde olmasıdır (Kelleci, 2009: 11). 
Yalova Sosyal Bilimler Dergisi

Rekabet gücü kavramı ele alınan alana (firma, endüstri ve ülke) rekabet gücünü belirlemede kullanılan ölçütlere ve bakış açısına bağlı olarak (mikro veya makro) farklı biçimlerde tanımlanmaktadır (Aktan ve Vural, 2004: 11). Firma düzeyinde yüksek kalitede düşük maliyette üretim becerisi olarak tanımlanan rekabet gücünün temel belirleyicileri kalite, maliyet ve fiyat unsurları olmaktadır. Verimlilik, organizasyon ve yönetim yapısı, etkin kaynak kullanımı ve yenilik yaratma becerisi de rekabet gücünü etkilemektedir. Endüstriyel rekabet ise bir endüstrinin rakiplerine göre daha üst bir verimlilik düzeyine ulaşması, daha düşük maliyetle üretim ve satış yapması ve bu becerileri sürdürülebilir kılması, gereken icat ve yenilikleri gerçekleştirebilmesi olarak tanımlanmaktadır. Uluslararası düzeyde ise serbest ve adil piyasa koşullarında uluslararası piyasaların standartlarına uygun üretim yapabilme yeteneği olarak tanımlanmakta, dış pazar paylarının arttırılması ve dış ticaret dengesinin sağlamasının yanı sıra ülkedeki gelir ve istihdam düzeyini arttırmak ve yaşam kalitesinin sürekli arttırılması olarak değerlendirilmektedir (Kirankabeş, 2006).

Yukarıdaki açıklamalara göre rekabet gücüne sahip olmak, ülke refahının ve yaşam standartlarının artması demektir. $\mathrm{Bu}$ ise ticaret, yatırım ve üretim faaliyetlerinde artış sağlaması, ülke içi kurumlar arasında işbirliğinin tesis edilmesi ve uzmanlaşma ile mümkün olmaktadır. Mal ve hizmetlerin üretilmesinde, pazarlanmasında ve dağıtılmasında diğer ülkelerle rekabet edebilmek için ülke yeteneklerinin geliştirilmesi ve yeni potansiyellerin yaratılması gerekmektedir (Çivi, 2001: 25).

\section{Literatür Araştırması}

Literatürde tarımsal ürünlerin rekabet gücünü belirlemeye yönelik birçok ulusal ve uluslararası düzeyde çalışmalar mevcuttur. Bu bölümde söz konusu çalışmalardan bazıları ile ilgili kısa bilgiler sunulmaktadır. Gorton ve ark. (2000), çalışmalarında Bulgaristan ve Çek Cumhuriyeti tarım sektörünün $\mathrm{AB}$ ülkeleri karşısındaki rekabet gücünü belirlemeye yönelik çalışmalarında açıklanmış karşılaştırmalı üstünlükler (AKÜ) ve iç kaynak maliyeti (DRC) yöntemlerini kullanmışlardır. Araştırmada Bulgaristan ve Çek Cumhuriyeti'nin hububat ihracatında karşılaştırmalı üstünlüğe sahip olduğunu belirlemişlerdir. Fertö ve Hubbard (2003), yaptıkları çalışmalarında Macaristan'ın tarımsal ürünlerdeki rekabet gücünü analiz etmiş̧lerdir. Araştırmada Balassa ve Vollrath tarafından geliştirilen indeksler kullanmışlardır. Araştırma sonucunda Macaristan'ın gıda ve tarım ürünlerinde özellikle hayvansal gıda ürünlerinde karşılaştırmalı üstünlüğe sahip olduğu tespit edilmiştir.

Kagochi (2007), ABD’nin başlıca tarım ürünlerindeki (buğday, mısır, pamuk ve soya fasulyesi) rekabet gücü analiz edilmiştir. Araştırmada Balassa'nın açıklanmış karşılaştırmalı üstünlükler indeksi ve Michaely indeksi kullanılmıştır. Sonuç olarak, ABD'nin ele alınan tarım ürünlerinde rekabet gücüne sahip olduğu tespit edilmiştir. Levkovych (2008), 1996-2005 dönemi için Orta Asya ülkelerinin pamuk ve buğday ihracatındaki rekabet gücünü analiz etmiştir. Araştırmada Vollrath ve Grubel-Lloyd indeksleri kullanılmıştır. Sonuç olarak buğday ihracatında Orta Asya ülkelerinden sadece Kazakistan rekabet gücüne sahip iken, pamuk ihracatında ise Orta Asya ülkelerinin tamamının rekabet gücüne sahip oldukları saptanmıştır. 
Yalova Sosyal Bilimler Dergisi

Bielik ve Qineti (2010), Çek Cumhuriyeti ve Slovakya'nın tarım ürünleri ticaretinde $\mathrm{AB}$ ülkeleri karşısındaki karşılaştırmalı üstünlüğünü analiz etmişlerdir. Araştırmada tarım ürünlerine ilişkin AKÜ katsayıları hesaplanmıştır. Araştırma sonucunda her iki ülkenin tarım ürünlerinde karşılaştırmalı üstünlüklerinin sürekli arttığı tespit edilmiştir.

Bakhshinejad ve Hassanzadeh (2012), İran'ın seçilmiş tarım ürünlerindeki (ceviz, badem, fındık, elma ve portakal) karşılaştırmalı üstünlüğü analiz edilmiştir. Araştırmada açıklanmış karşılaştırmalı üstünlükler indeksi kullanılmıştır. Sonuç olarak İran'ın söz konusu ürünlerde karşılaştırmalı dezavantaja sahip olduğu belirlenmiştir. Çalışmada ayrıca İran'ın rekabet gücünün artırılması için tarımsal verimliliğin artırılması, yerli teknolojinin geliştirilmesi ve iş yapma maliyetinin azaltılması gibi öneriler sunulmuştur. Kanaka ve Chinadurai (2012), Hindistan'ın seçilmiş tarım ürünlerindeki karşılaştırmalı üstünlüğü açıklanmış karşılaştırmalı üstünlükler indeksi kullanarak analiz edilmiştir. Araştırma bulgularına göre Hindistan pirinç, çay, yer fistığı gibi ürünlerde karşılaştırmalı üstünlüğe sahiptir.

Ishchukova ve Smutka (2013), Rusya tarım sektörünün uluslararası rekabet gücünü Balassa, Vollrath ve Lafay indekslerini kullanarak analiz etmiş̧lerdir. Analiz sonucunda Rusya'nın daha çok tahıllar, bitkisel yağ ve yağlı tohumlar, tütün ve tütün mamulleri ihracatında karşıllaştırmalı üstünlüğe sahip olduğu; buna karşın hayvansal ürünler ile meyve ve sebze ihracatında karşılaştırmalı dezavantaja sahip olduğu belirlenmiştir. Sarker ve Ratnasena (2014), 1961-2011 dönemi için Kanada'nın başlıca tarım ürünlerindeki (buğday, sığır eti ve domuz eti) rekabet gücünü analiz etmişlerdir. Araştırmada Balassa'nın AKÜ indeksinden yararlanılmıştır. Araştırma bulgularına göre Kanada buğday ihracatında karşılaştırmalı avantaja sahip iken, sığır eti ve domuz eti ihracatında karşılaştırmalı dezavantaja sahiptir.

Bashimov (2015), Açılanmış karşılaştırmalı üstünlükler ve net ticaret indeksleri kullanılarak Özbekistan'ın pamuk ihracatındaki rekabetçilik düzeyi incelenmiştir. 2001-2013 yılları için hesaplanan indeks değerlerine göre Özbekistan pamuk ihracatında güçlü bir karşılaştırmalı üstünlüğe sahiptir. Ancak, incelenen dönemde Özbekistan'ın pamuk ihracatındaki rekabet gücünün giderek zayıfladığ saptanmıştır. Araştırmada Özbekistan'ın rekabet gücünün artırılması için tarımsal üretimde kalite ve verimliliğin artırılması, AR-GE yatırımlarının teşvik edilmesi ve pazarlama zincirinin etkinleştirilmesi gibi öneriler sunulmuştur.

Erkan ve ark. (2015), Türkiye'nin sebze ihracatında rekabet gücünü analiz etmişlerdir. Araştırmada 1993-2012 dönemi için AKÜ katsayısı hesaplanmıştır. Araştırma sonucunda Türkiye'nin sebze ve alt grupları ihracatında küresel piyasalarda önemli bir karş1laştırmalı üstünlüğe sahip olduğu tespit edilmiştir. Bununla birlikte, sebze alt gruplarının büyük çoğunluğunun ihracatında karş1laştırmalı üstünlügün olmasına rağmen, son yıllardaki üstünlüklerin nispi anlamda azaldığ 1 belirlenmiştir. Peker (2015), Türkiye hububat-baklagil alt sektörünün Avrupa Birliği pazarı karşısındaki rekabet gücünü analiz etmiştir. $\mathrm{Bu}$ amaçla hububat-baklagil alt sektörüne ilişkin açıklanmış karşılaştırmalı üstünlükler indeksi hesaplanmıştır. Araştırma sonucunda Türkiye'nin AB pazarı karşısında 
Yalova Sosyal Bilimler Dergisi

mercimek ve nohutta yüksek rekabet gücüne sahip olduğu belirlenirken, kuru fasulye, buğday ve misır ürünlerinde ise rekabet üstünlüğüne sahip olmadığ belirlenmiştir.

Bashimov (2016), 1995-2014 dönemi için Türk domatesinin uluslararası rekabet gücü analiz edilmiştir. Araştırmada Balassa'nın Açıklanmış Karşılaştırmalı Üstünlükler indeksi ve Vollrath'ın Göreli İhracat Avantajı indeksi kullanılmıştır. Sonuç olarak, Türkiye'nin domates ihracatında rekabet gücü yüksek buunmuştur. Ancak, son bir kaç yıldır rekabet gücüne ilişkin hesaplanan indeks değerlerinde belirgin bir düşüş göze çarpmaktadır. Çiçek ve Bashimov (2016), 2001-2012 dönemi için Orta Asya ülkelerinin pamuk ticaretindeki karşıllaştırmalı üstünlügüü analiz edilmiştir. Araştırmada açıklanmış karşılaştırmalı üstünlükler indeksi ile birlikte net ticaret indeksi kullanılmıştır. Araştırma sonucunda Orta Asya ülkelerinin (Kazakistan hariç) pamuk ticaretinde karşılaştırmalı üstünlüğe sahip oldukları belirlenmiştir. Çalışmada Orta Asya ülkelerinin rekabet gücünün artırılması için tarım sektörüne yönelik altyapı ve teknoloji yatırımlarına önem verilmesi ve tarımsal üretimde verimliliğin artırılması gibi öneriler sunulmuştur.

\section{Materyal ve Yöntem}

$\mathrm{Bu}$ çalışmada ulusal ve uluslararası düzeydeki raporlar, araştırmalar ve istatistiklerden ikincil veriler olarak yararlanılmıştır. Elde edilen veriler analiz edilmiş ve değerlendirilmiştir. Çalışmada Uyumlaştırılmış Mal Tanım ve Kod Sistemi (Harmonized Commodity Desctription and Coding System) HS 2 haneli ürün sınıflandırması kullanılmıştır. Söz konusu sınıflandırmaya göre meyve sektörünün kod numarası HS 08 ve sebze sektörünün kod numarası ise HS 07'dir. Araştırmada kullanılan veriler dolar bazında olup, söz konusu veriler Uluslararası Ticaret Merkezi'nin istatistiki veri tabanından derlenmiştir. Araştırma 2002-2015 dönemini kapsamaktadır.

Orta Asya ülkelerinin meyve ve sebze sektöründe rekabet gücünün ölçümünde Açıklanmış Karşılaştırmalı Üstünlükler ve Net İhracat İndeksi kullanılmıştır. Açıklanmış Karşılaştırmalı Üstünlükler (AKÜ) indeksi ilk kez Liesner (1958) tarafindan ortaya atılmış, daha sonra ise Bela Balassa (1965) tarafından yeniden tanımlanarak geliştirilmiş ve Balassa indeksi olarak da adlandırılmaktadır. Açıklanmış Karşılaştırmalı Üstünlükler kavramı, belli bir malın ihracatında, bir ülkenin gösterdiği performansın, bu malın "dünya" ihracatındaki performansıyla karşılaştırılmasına dayanır. Eğer ülkenin performansı, "dünya"nın performansından daha iyi ise, o ülkenin söz konusu malda karşlaştırmalı üstünlüğe sahip olduğu sonucuna varılır (Erlat ve Erlat, 2004: 49). Günümüzde Balassa'nın AKÜ indeksi bir ülkenin güçlü ve zayıf ihracatçı sektörlerini belirlemeye yönelik birçok çalışmalarda kullanılmaktadır (Fertö ve Bojnec, 2007: 7). Balassa'nın AKÜ indeksi şu şekilde formüle edilmektedir:

$$
\mathrm{AKU}_{\mathrm{ij}}=\left[\left(\frac{\mathrm{C}_{\mathrm{ij}}}{\mathrm{x}_{\mathrm{it}}}\right) /\left(\frac{\mathrm{x}_{\mathrm{wj}}}{\mathrm{x}_{\mathrm{wt}}}\right)\right]
$$


Yalova Sosyal Bilimler Dergisi

Eşitlik 1'de, AKÜ̈ $\mathrm{Ui}_{\mathrm{ij}}$ ' ‘' ülkesinin ' $\mathrm{j}$ ' sektörü için açıklanmış karşılaştırmalı üstünlükler indeksini, $X_{\mathrm{ij}}$ ' $\mathrm{i}$ ' ülkesinin ' $\mathrm{j}$ ' sektörünün ihracatını, $X_{\mathrm{it}}$ ' $\mathrm{i}$ ' ülkesinin toplam ihracatını, $X_{w j}$ ' $j$ ' sektörü dünya ihracatını ve $X_{w t}$ toplam dünya ihracatını göstermektedir. AKÜ indeksi 0 ile $\infty$ arasında bir değer almaktadır. Eğer indeks değeri birden büyükse o ülkenin ilgili sektörde karşılaştırmalı üstünlüğe sahip olduğu söylenir. Başka bir deyişle, o endüstrinin ülkenin toplam ihracatı içindeki payı, dünya ticaretindeki payından daha büyüktür. Eğer indeks değeri birden az ise ülkenin ilgili sektörde karşılaştırmalı dezavantaja sahip olduğu söylenir (Mushanyuri ve Mzumara, 2013: 38; Peker, 2015: 10).

Yukarıda ifade edildiği gibi açıklanmış karşılaştırmalı üstünlügün olup olmadığı indeks değerinin 1'den büyük ya da küçük olmasına göre belirlenir. Bunun yanında daha ayrıntılı olarak karşılaştırmalı üstünlügün gücünü göstermek amacıyla Balassa'nın AKÜ katsayısı aşağıdaki gibi 4 şekilde sınıflandırılabilir (Hinloopen ve Marrewijk, 2001: 13):

1.Sınıflama: $0<$ AKÜ $\leq 1$ : Karşılaştırmalı üstünlük yoktur.

2.Sınıflama: $1<$ AKÜ $\leq 2$ : Zayıf bir karşılaştırmalı üstünlük vardır.

3.Sınıflama: $2<A K U ̈ \leq 4$ : Orta derecede karşılaştırmalı üstünlük vardır.

4.Sınıflama: 4 < AKÜ: Güçlü bir karşılaştırmalı üstünlük vardır.

Orta Asya ülkelerinin yaş meyve ve sebze sektörünün rekabet gücünün belirlenmesinde kullanılan diğer bir indeks ise Net Ticaret İndeksidir. Alternatif bir açıklanmış karşılaştırmalı üstünlük indeksi olarak da bilinen net ticaret indeksi, ülkenin sadece kendi ticari performansının ölçümünü yapmak amacıyla hesaplanmaktadır (Özçalık ve Okur, 2013: 212). Net Ticaret İndeksi şu şekilde formüle edilmektedir:

$N T \dot{I}_{i j}=\left(X_{i j}-M_{i j}\right) /\left(X_{i j}+M_{i j}\right)$

Eşitlk 2'de, $X_{i j}$ “i” ülkesinin “j” sektörünün ihracatını ve $M_{i j}$ " $i$ ” ülkesinin “j” sektörünün ithalatını göstermektedir. Net ticaret indeksi -1 ve +1 arasında bir değer almaktadır (Amighini, 2005). Net ticaret indeksinin pozitif değer alması söz konusu ülkenin o mal ve hizmette açılanmış karşılaştırmalı üstünlüğünün olduğunu, negatif değer alması ise açılanmış karşılaştırmalı üstünlüğünün bulunmadığını gösterir (Özçalık ve Okur, 2013: 212).

Orta Asya ülkelerinin meyve ve sebze sektörünün endüstri-içi ticaret düzeyinin ölçümünde Grubel-Lloyd indeksi kullanılmıştır. Grubel-Lloyd indeksi, bir sektörün veya ülkenin endüstri-içi ticaret düzeyini ve aynı zamanda uzmanlaşma düzeyinin belirlenmesinde kullanılan popüler bir yaklaşımdır (Hazners ve Jirgena, 2013: 63). Bilimsel çalışmalarda sıkça kullanılan Grubel-Lloyd (GL) indeksi aşağıdaki şekilde formüle edilmektedir (Erlat ve Erlat, 2004: 51):

$\mathrm{GL}_{\mathrm{ij}}=\frac{\left(\mathrm{x}_{\mathrm{ij}}+\mathrm{M}_{\mathrm{ij}}\right)-\left|\mathrm{x}_{\mathrm{ij}}-\mathrm{M}_{\mathrm{ij}}\right|}{\left(\mathrm{x}_{\mathrm{ij}}+\mathrm{M}_{\mathrm{ij}}\right)}$ 
Yalova Sosyal Bilimler Dergisi

Burada (Eşitlik 3), $G_{i j}$ ' $i$ ' ülkesinin ' $j$ ' sektörü için endüstri-içi ticaret düzeyini, $X_{i j}$ ve $M_{i j}$ srrasıyla ' $i$ ' ülkesinin ' $j$ ' sektörünün ihracatını ve ithalatını ifade etmektedir. GL indeksi 0 ile 1 arasında bir değer almaktadır. İndeks değerinin 1'e yaklaşması endüstri-içi ticarete işaret ederken, 0 'a yaklaşması ise endüstriler-arası ticarete işaret etmektedir. Yani indeks değeri 0,50 ile 1 arasında ise endüstri-içi ticaret, 0 ile 0,50 arasında ise endüstriler-arası ticaret söz konusu olmaktadır (Leitão ve Faustino, 2008: 52; Y1lmaz, 2014: 253).

\section{Bulgular}

\subsection{Rekabet Gücünün Ölçümü}

Orta Asya ülkelerinin meyve ihracatına ait AKÜ katsayıları Tablo 1'de sunulmaktadır. Buna göre Orta Asya ülkelerinden Özbekistan, Kırgızistan ve Tacikistan'1n meyve sektörüne ait AKÜ indeks değeri 1'in üzerinde değer almaktadır. Bu da söz konusu ülkelerin meyve sektöründe rekabet gücüne sahip olduğunu göstermektedir. Buna karşın Türkmenistan ve Kazakistan'ın meyve sektöründe rekabet gücünün düşük olduğu görülmektedir $(A K U ̈<1)$. Tablo 1'den de görüleceği gibi Ö̈zbekistan'ın AKÜ indeks değeri diğer ülkelere göre yüksek seviyededir. Özbekistan'1 sırasıyla Tacikistan ve Kırgizistan takip etmektedir. Hesaplanan AKÜ katsayılarına göre Özbekistan ve Tacikistan meyve ihracatında güçlü bir karşılaştırmalı üstünlüğe (4<AKÜ) sahipken, Kırgızistan ise zayıf bir karşılaştırmalı üstünlüğe $(1<\mathrm{AKU} \ddot{U} \leq 2)$ sahiptir. İncelenen dönemde Özbekistan, Tacikistan ve Kırgızistan'ın meyve ihracatına ait AKÜ katsayıları dalgalı bir seyir izlemektedir. Ancak özellikle 2011 yılından bu yana AKÜ katsayılarında bir düşüş göze çarpmaktadır (Şekil 1). Bu da söz konusu ülkelerin meyve ihracatındaki rekabet gücünün azaldığına işaret etmektedir.

Tablo 1: Meyve Sektörüne Ait AKÜ İndeks Değerleri

\begin{tabular}{lccccc}
\hline Yıllar & Türkmenistan & Özbekistan & Kazakistan & Kırgızistan & Tacikistan \\
\hline 2002 & 0,01 & 4,02 & 0,21 & 2,09 & 10,22 \\
2003 & 0,05 & 5,00 & 0,18 & 1,64 & 6,07 \\
2004 & 0,08 & 8,89 & 0,39 & 1,28 & 7,82 \\
2005 & 0,06 & 11,73 & 0,18 & 1,26 & 8,19 \\
2006 & 0,19 & 15,46 & 0,16 & 3,01 & 12,40 \\
2007 & 0,09 & 9,76 & 0,25 & 5,98 & 12,82 \\
2008 & 0,03 & 5,56 & 0,18 & 6,93 & 19,13 \\
2009 & 7,09 & 0,16 & 5,47 & 24,98 \\
2010 & 10,02 & 0,02 & 4,41 & 17,10 \\
2011 & 0,08 & 14,88 & 0,02 & 4,11 & 8,20 \\
2012 & 0,09 & 12,76 & 0,05 & 6,72 & 8,93 \\
2013 & 0,07 & 8,17 & 0,04 & 5,70 & 6,82 \\
2014 & 0,03 & 8,89 & 0,03 & 3,67 & 7,60 \\
2015 & 0,03 & 6,93 & 0,06 & 1,57 & 4,92 \\
\hline
\end{tabular}

Kaynak: INTRACEN verileri kullanılarak yazar tarafindan hesaplanmıştır. 
Yalova Sosyal Bilimler Dergisi

Şekil 1: Orta Asya Ülkelerinin Meyve Sektörüne Ait AKÜ İndeks Değerleri

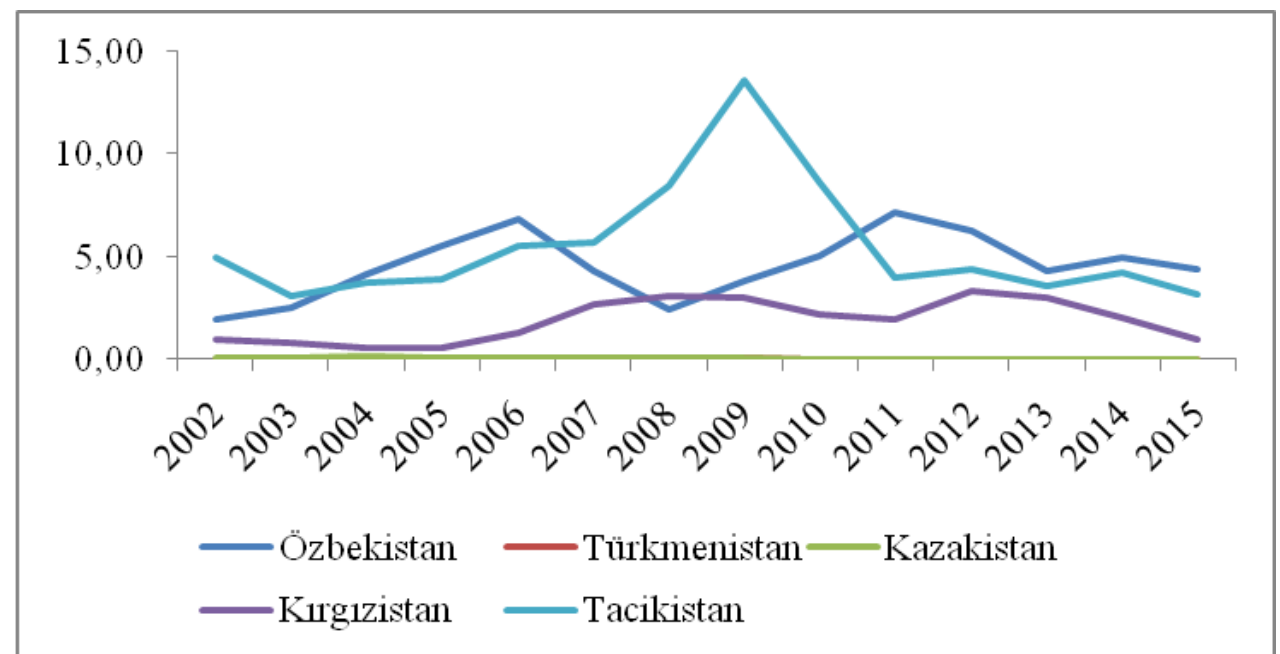

Kaynak: www.intracen.org

Orta Asya ülkelerinin sebze ihracatına ait AKÜ katsayıları Tablo 2'de sunulmaktadır. Buna göre Orta Asya ülkelerinden Özbekistan, Kırgizistan ve Tacikistan sebze ihracatında yüksek rekabet gücüne sahipken, Türkmenistan ve Kazakistan'ın rekabet gücünün düşük olduğu görülmektedir. Tablo 2'den de görüleceği gibi Kırgızistan'ın AKÜ indeks değeri diğer ülkelere göre yüksek seviyededir. Kırgızistan'1 sırasıyla Özbekistan ve Tacikistan takip etmektedir. Hesaplanan AKÜ katsayılarına göre Kırgızistan, Özbekistan ve Tacikistan sebze ihracatında güçlü bir karşılaştırmalı üstünlüğe $(4<A K \ddot{)})$ sahiptirler. İncelenen dönemde Kırgızistan, Özbekistan ve Tacikistan'ın sebze ihracatına ait AKÜ değerlerinde genel olarak bir artış görülmektedir (Şekil 2). Sonuç olarak söz konusu ülkelerin sebze ihracatındaki rekabet güçlerinin giderek yükseldiği söylenebilir.

Tablo 2: Sebze Sektörüne Ait AKÜ İndeks Değerleri

\begin{tabular}{lccccc}
\hline Yıllar & Türkmenistan & Özbekistan & Kazakistan & Kırgızistan & Tacikistan \\
\hline 2002 & 0,09 & 3,98 & 0,40 & 6,04 & 3,91 \\
2003 & 0,09 & 6,05 & 0,33 & 3,58 & 4,24 \\
2004 & 0,17 & 6,68 & 0,80 & 6,49 & 4,30 \\
2005 & 0,18 & 9,12 & 0,38 & 6,30 & 3,83 \\
2006 & 0,11 & 6,83 & 0,39 & 9,37 & 4,03 \\
2007 & 0,04 & 7,03 & 0,39 & 13,03 & 10,22 \\
2008 & 0,03 & 2,70 & 0,37 & 8,66 & 9,58 \\
2009 & 0,06 & 4,21 & 0,18 & 9,79 & 7,10 \\
2010 & 0,07 & 8,45 & 0,10 & 11,99 & 11,05 \\
2011 & 0,09 & 9,62 & 0,02 & 13,98 & 5,40 \\
2012 & 0,06 & 6,33 & 0,10 & 16,57 & 4,11 \\
2013 & 0,06 & 7,66 & 0,04 & 17,54 & 6,60 \\
2014 & 0,03 & 8,66 & 0,06 & 14,08 & 3,99 \\
2015 & 0,04 & 6,86 & 0,11 & 5,61 \\
\hline
\end{tabular}

Kaynak: INTRACEN verileri kullanılarak yazar tarafından hesaplanmıştır. 
Yalova Sosyal Bilimler Dergisi

Şekil 2: Orta Asya Ülkelerinin Sebze Sektörüne Ait AKÜ İndeks Değerleri

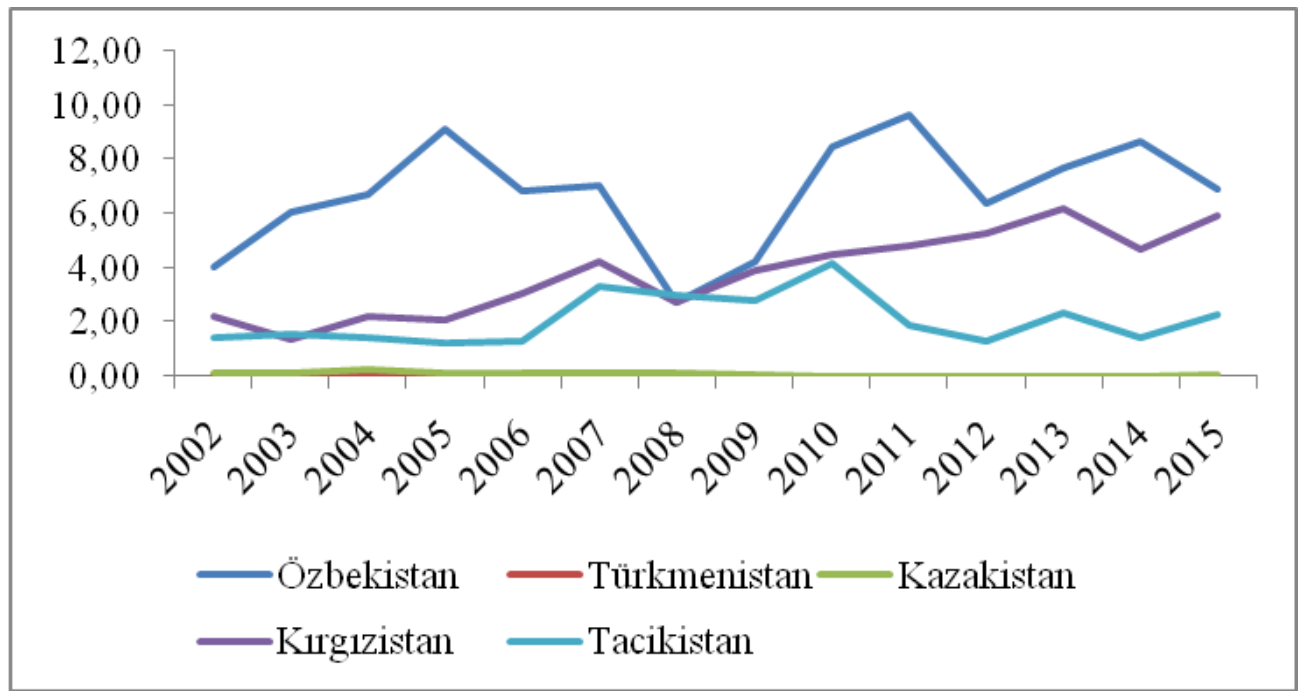

Kaynak: www.intracen.org

Tablo 3'de Net Ticaret İndeksine (NTI) göre Orta Asya ülkelerinin meyve sektöründeki rekabet gücü değerleri yer almaktadır. Buna göre Özbekistan ve Tacikistan'ın meyve sektörüne ait NTİ değerleri ele alınan bütün yıllarda pozitif bir değer almıştır. Yani söz konusu iki ülke meyve sektöründe net ihracatçı ülke konumundadır. Kırgızistan 2005, 2006 ve 2015 yıllarında meyve sektöründe net ithalatçı iken, diğer yıllarda ise net ihracatçı ülkedir. Türkmenistan ve Kazakistan'ın ise meyve sektöründe net ithalatçı olduğu görülmektedir (Tablo 3 ve Şekil 3).

Tablo 3: Meyve Sektörüne Ait Net Ticaret İndeks Değerleri

\begin{tabular}{lccccc}
\hline Yıllar & Türkmenistan & Özbekistan & Kazakistan & Kırgızistan & Tacikistan \\
\hline 2002 & $-0,93$ & 0,94 & 0,02 & 0,61 & 0,98 \\
2003 & $-0,82$ & 0,89 & $-0,14$ & 0,50 & 0,95 \\
2004 & $-0,72$ & 0,93 & 0,33 & 0,06 & 0,93 \\
2005 & $-0,72$ & 0,95 & $-0,08$ & $-0,27$ & 0,91 \\
2006 & $-0,37$ & 0,97 & $-0,14$ & $-0,08$ & 0,86 \\
2007 & 0,96 & 0,99 & $-0,05$ & 0,43 & 0,99 \\
2008 & $-0,66$ & 0,99 & $-0,27$ & 0,54 & 0,99 \\
2009 & $-0,02$ & 0,97 & $-0,56$ & 0,32 & 0,97 \\
2010 & $-0,95$ & 0,97 & $-0,95$ & 0,17 & 0,73 \\
2011 & $-0,85$ & 0,97 & $-0,96$ & 0,30 & 0,59 \\
2012 & $-0,51$ & 0,98 & $-0,94$ & 0,42 & 0,93 \\
2013 & $-0,60$ & 0,97 & $-0,94$ & 0,20 & 0,79 \\
2014 & $-0,42$ & 0,96 & $-0,96$ & 0,07 & 0,62 \\
2015 & $-0,77$ & 0,96 & $-0,93$ & $-0,21$ & 0,78 \\
\hline Kaynat & - & 0 & & & \\
\hline
\end{tabular}

Kaynak: INTRACEN verileri kullanılarak yazar tarafindan hesaplanmıştır. 
Yalova Sosyal Bilimler Dergisi

Şekil 3: Meyve Sektörüne Ait Net Ticaret İndeks Değerleri

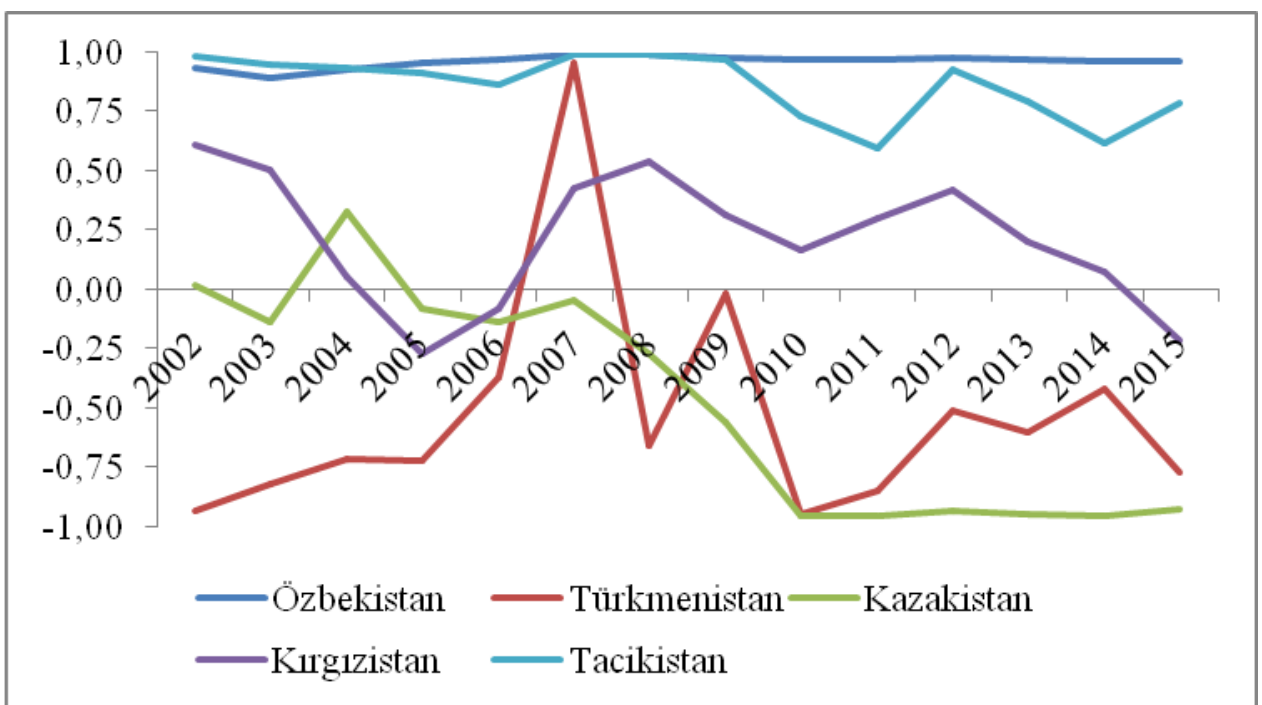

Kaynak: www.intracen.org

Tablo 4'de Net Ticaret İndeksine göre Orta Asya ülkelerinin sebze sektöründeki rekabet gücü değerleri gösterilmiştir. Özbekistan, Kırgızistan ve Tacikistan'ın sebze sektörüne ait net ticaret indeks değerleri ele alınan bütün yıllarda pozitif bir değer almıştır. Söz konusu ülkeler sebze sektöründe net ihracatçı ülkelerdir. Ancak son birkaç yıldır net ticaret indeks değerlerinde bir düşüş göze çarpmaktadır. Türkmenistan son 10 yıldır sebze sektöründe net ithalatçı ülke konumundadır. Kazakistan ise 2002-2008 y1lları arasında net ihracatçı ülke iken, 2009 yılından bu yana net ithalatçı ülke konumundadır (Şekil 4).

Tablo 4: Sebze Sektörüne Ait Net Ticaret İndeks Değerleri

\begin{tabular}{lccccc}
\hline Yıllar & Türkmenistan & Özbekistan & Kazakistan & Kırgızistan & Tacikistan \\
\hline 2002 & 0,46 & 0,87 & 0,53 & 0,98 & 0,60 \\
2003 & $-0,13$ & 0,98 & 0,70 & 0,94 & 0,68 \\
2004 & 0,54 & 0,99 & 0,81 & 0,95 & 0,68 \\
2005 & 0,00 & 0,99 & 0,75 & 0,95 & 0,72 \\
2006 & $-0,57$ & 0,95 & 0,61 & 0,92 & 0,49 \\
2007 & $-0,29$ & 0,89 & 0,54 & 0,93 & 0,89 \\
2008 & $-0,52$ & 0,86 & 0,41 & 0,92 & 0,74 \\
2009 & $-0,86$ & 0,86 & $-0,10$ & 0,92 & 0,76 \\
2010 & $-0,96$ & 0,91 & $-0,64$ & 0,93 & 0,78 \\
2011 & $-0,89$ & 0,92 & $-0,93$ & 0,93 & 0,74 \\
2012 & $-0,48$ & 0,77 & $-0,81$ & 0,96 & 0,49 \\
2013 & $-0,75$ & 0,87 & $-0,92$ & 0,95 & 0,79 \\
2014 & $-0,69$ & 0,83 & $-0,88$ & 0,88 & 0,49 \\
2015 & $-0,43$ & 0,74 & $-0,84$ & 0,88 & 0,22 \\
\hline
\end{tabular}

Kaynak: INTRACEN verileri kullanılarak yazar tarafindan hesaplanmıştır. 
Yalova Sosyal Bilimler Dergisi

Şekil 4: Sebze Sektörüne Ait Net Ticaret İndeks Değerleri

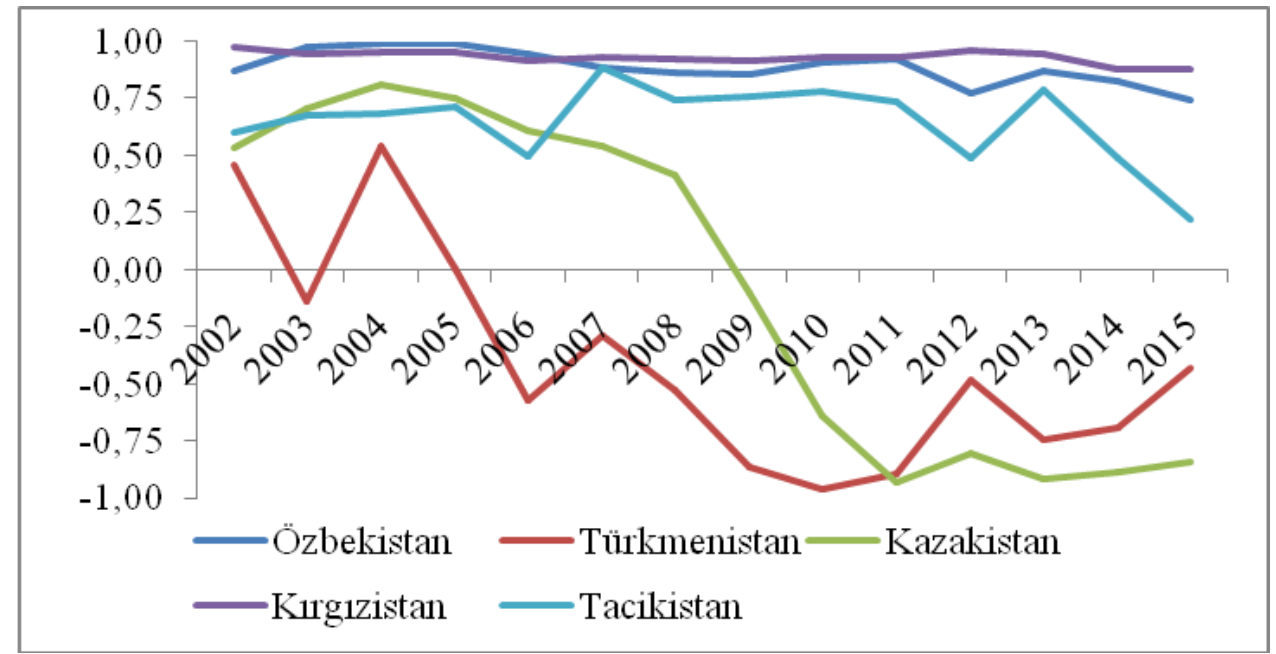

Kaynak: www.intracen.org

\subsection{Endüstri-Ị̇i Ticaretin Ölçümü}

Tablo 5'de Orta Asya ülkelerinin meyve sektörünün endüstri-içi ticaret rakamları gösterilmektedir. 2002-2015 yılları arasında Özbekistan ve Tacikistan'da endüstriiçi ticaret oranı (GL indeksi) sürekli 0,50'nin altında seyretmiştir. Türkmenistan'da 2006, 2009 ve 2014 yılları hariç GL indeks değeri 0,50'nin altında seyretmiştir. 2002-2008 dönemde Kazakistan'da endüstri-içi ticaret seviyesinin yüksek seyrettiği görülürken, 2009-2015 yılları dönemde ise endüstri-içi ticaret seviyesinin düşük olduğu görülmektedir. Kırgızistan'da 2002 ve 2008 yılları hariç diğer yıllarda endüstri-içi ticaret oranı yüksek seyretmiştir (Şekil 5). Genel itibariyle değerlendirildiğinde Kırgızistan hariç diğer ülkelerin meyve sektöründe endüstriiçi ticaret seviyesinin düşük olduğu görülmektedir.

Tablo 5: Meyve Sektörüne Ait Grubel-Lloyd İndeks Değerleri

\begin{tabular}{lccccc}
\hline Yıllar & Türkmenistan & Özbekistan & Kazakistan & Kırgızistan & Tacikistan \\
\hline 2002 & 0,07 & 0,06 & $0,98^{*}$ & 0,39 & 0,02 \\
2003 & 0,18 & 0,11 & $0,86^{*}$ & $0,50^{*}$ & 0,05 \\
2004 & 0,28 & 0,07 & $0,67^{*}$ & $0,94^{*}$ & 0,07 \\
2005 & 0,28 & 0,05 & $0,92^{*}$ & $0,73^{*}$ & 0,09 \\
2006 & $0,63^{*}$ & 0,03 & $0,86^{*}$ & $0,92^{*}$ & 0,14 \\
2007 & 0,04 & 0,01 & $0,95^{*}$ & $0,57^{*}$ & 0,01 \\
2008 & 0,34 & 0,01 & $0,73^{*}$ & 0,46 & 0,01 \\
2009 & $0,98^{*}$ & 0,03 & 0,44 & $0,68^{*}$ & 0,03 \\
2010 & 0,05 & 0,03 & 0,05 & $0,83^{*}$ & 0,27 \\
2011 & 0,15 & 0,03 & 0,04 & $0,70^{*}$ & 0,41 \\
2012 & 0,49 & 0,02 & 0,06 & $0,58^{*}$ & 0,07 \\
2013 & 0,40 & 0,03 & 0,06 & $0,80^{*}$ & 0,21 \\
2014 & $0,58^{*}$ & 0,04 & 0,04 & $0,93^{*}$ & 0,38 \\
2015 & 0,23 & 0,04 & 0,07 & $0,79^{*}$ & 0,22 \\
\hline
\end{tabular}

Kaynak: INTRACEN verileri kullanılarak yazar tarafindan hesaplanmıştır.

*Endüstri-içi ticaretin olduğunu göstermektedir 
Yalova Sosyal Bilimler Dergisi

Şekil 5: Orta Asya Ülkelerinin Meyve Sektöründe GL İndeks Değerleri

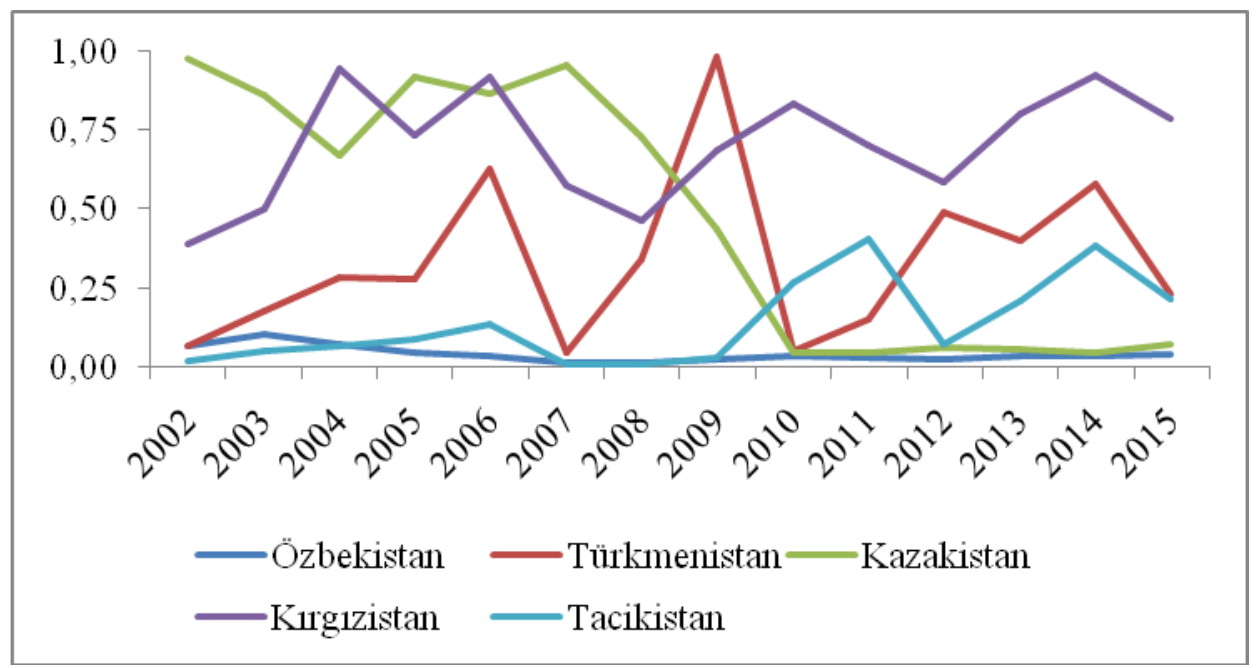

Kaynak: www.intracen.org

Orta Asya ülkelerinin sebze sektörüne ait endüstri-içi ticaret rakamları Tablo 6'de sunulmaktadır. Orta Asya ülkelerinin sebze sektöründe endüstri-içi ticaret seviyesinin düşük olduğu görülmektedir. Diğer bir anlatımla ticaretin daha çok endüstriler-arası ticaret şeklinde gerçekleştiği görülmektedir. 2002-2015 yılları arasında Özbekistan ve Kırgızistan'da endüstri-içi ticaret oranı (GL indeksi) sürekli 0,50'nin altında seyretmiştir. Kazakistan'da 2008-2009 yılları hariç diğer bütün yıllarda GL indeksi 0,50'nin altında bir değer almıştır. Türkmenistan'da GL indeks değeri 2002, 2003, 2005, 2007, 2012 ve 2015 yıllarında 0,50'nin üzerinde bir değer alırken, diğer yıllarda indeks değeri 0,50'nin altında kalmıştır. Tacikistan'da ise 2006, 2012, 2014 ve 2015 y1llarında GL indeks değeri 0,50'nin üzerinde değer almışken, diğer yıllarda 0,50'nin altında bir değer almıştır (Tablo 6 ve Şekil 6). Sonuç olarak, Orta Asya ülkelerinin sebze sektöründe endüstri-içi ticaret seviyesinin düşük olduğu görülmektedir.

Tablo 6: Sebze Sektörüne Ait Grubel-Lloyd İndeks Değerleri

\begin{tabular}{lccccc}
\hline Yıllar & Türkmenistan & Özbekistan & Kazakistan & Kırgızistan & Tacikistan \\
\hline 2002 & $0,54^{*}$ & 0,13 & 0,47 & 0,02 & 0,40 \\
2003 & $0,87^{*}$ & 0,02 & 0,30 & 0,06 & 0,32 \\
2004 & 0,46 & 0,01 & 0,19 & 0,05 & 0,32 \\
2005 & $1,00^{*}$ & 0,01 & 0,25 & 0,05 & 0,28 \\
2006 & 0,43 & 0,05 & 0,39 & 0,08 & $0,51^{*}$ \\
2007 & $0,71^{*}$ & 0,11 & 0,46 & 0,07 & 0,11 \\
2008 & 0,48 & 0,14 & $0,59^{*}$ & 0,08 & 0,26 \\
2009 & 0,14 & 0,14 & $0,90^{*}$ & 0,08 & 0,24 \\
2010 & 0,04 & 0,09 & 0,36 & 0,07 & 0,22 \\
2011 & 0,11 & 0,08 & 0,07 & 0,07 & 0,26 \\
2012 & $0,52^{*}$ & 0,23 & 0,19 & 0,04 & $0,51^{*}$ \\
2013 & 0,25 & 0,13 & 0,08 & 0,05 & 0,21 \\
2014 & 0,31 & 0,17 & 0,12 & 0,12 & $0,51^{*}$ \\
2015 & $0,57^{*}$ & 0,26 & 0,16 & 0,12 & $0,78^{*}$ \\
\hline
\end{tabular}

Kaynak: INTRACEN verileri kullanılarak yazar tarafından hesaplanmıştır

*Endüstri-içi ticaretin olduğunu göstermektedir 
Yalova Sosyal Bilimler Dergisi

Şekil 6: Orta Asya Ülkelerinin Sebze Sektörüne Ait GL İndeks Değerleri

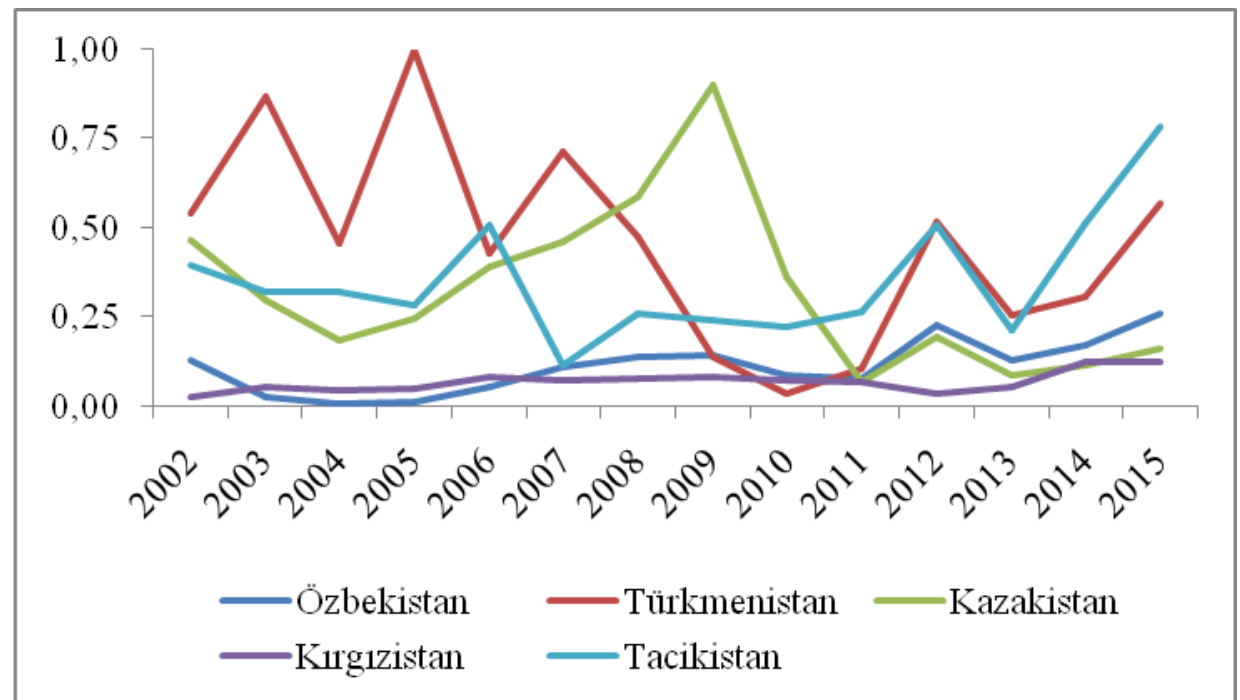

Kaynak: www.intracen.org

Elde edilen bulgular genel olarak değerlendirildiğinde Özbekistan, Kırgızistan ve Tacikistan'ın meyve ve sebze ihracatında karşılaştırmalı üstünlüğe sahip olduğu görülmektedir. Sovyetler Birliği'nin dağılması ile birlikte Orta Asya ülkelerinde hayata geçirilen reformlar sonucu meyve ve sebze üretiminde önemli artışlar elde edilmiştir. Söz konusu ülkelerde uygulanan gidada kendi kendine yeterlilik politikası sonucu meyve ve sebze ekim alanları zamanla pamuk ekim alanları lehine genişleme göstermiştir. Bugün küçük ölçekli aile işletmelerinde toplam ekili alanın yaklaşık yarısını meyve ve sebze alanları oluşturmaktadır. Son 10-15 yıllık dönemde meyve ve sebze üretimindeki artışa paralel olarak ihracat da önemli ölçüde artış göstermiştir. Örneğin, 2005-2015 döneminde yaş meyve ve sebze ihracatı Özbekistan'da \%30 ve Tacikistan'da \%23 oranında artı̧ göstermişken, Kırgızistan'da ise 5 kattan fazla bir artış görülmüsştür. Orta Asya ülkeleri sahip olduğu toprak ve iklim yapısı, yetişmiş insan gücü ve önemli pazarlara coğrafi yakınlığı nedeniyle, yaş meyve ve sebze ihracatı açısından önemli bir potansiyele sahiptir. Orta Asya ülkelerinin yaş meyve ve sebze ihracatındaki rekabet gücünün arttırılması için; üretimde verim arttırıcı yeni teknolojiler uygulanmalı, üretim maliyeti minimize edilmeli, ürün kalitesi yükseltilmeli, özel girişimcilik teşvik edilmeli, marka oluşumu teşvik edilmeli, ihracatta ürün ve pazar çeşitlendirmesine gidilmelidir.

\section{Sonuç}

Tarım sektörü sanayiye hammadde temin etmesi, ülkeye döviz girdisi sağlaması ve istihdama sağladığ 1 katkılarından dolayı Orta Asya ülkelerinde önemli bir sektörlerden birini oluşturmaktadır. Orta Asya ülkeleri sahip olduğu toprak ve ekolojik koşulları nedeni ile birçok tarım ürünlerinin üretimi açısından yeterli potansiyele sahiptir. Ancak, dünyada önemli ihracatçıları arasında yer alabilmek için üretim tek başına yeterli olamamaktadır. Üretim kadar ihracat değerinin de 
Yalova Sosyal Bilimler Dergisi

yüksek olması gerekmektedir. Dolayısıyla tarım ürünleri ihracatının da arttırılması oldukça büyük önem arz etmektedir.

$\mathrm{Bu}$ çalışmada Orta Asya ülkelerinde yaş meyve ve sebze sektörünün rekabet gücü ve endüstri-içi ticaret yapısı analiz edilmiştir. Çalışmada 2002-2015 dönemi analiz edilmiş olup, HS 2 haneli sınıflandırma düzeyi kullanılmıştır. Rekabet gücünün ölçümünde Açıklanmış Karşılaştırmalı Üstünlükler ve Net Ticaret İndeksleri kullanılırken, endüstri-içi ticaretin ölçümünde ise Grubel-Lloyd indeksi kullanılmıştır. Açıklanmış Karşılaştırmalı Üstünlükler indeks sonucuna göre ele alınan ülkelerden Özbekistan, Kırgızistan ve Tacikistan'ın yaş meyve ve sebze sektöründe rekabet gücüne sahip olduğu belirlenirken, Türkmenistan ile Kazakistan'ın yaş meyve ve sebze sektöründe rekabet gücünün düşük olduğu saptanmıştır. Net Ticaret İndeksine göre Özbekistan, Kırgızistan ve Tacikistan yaş meyve ve sebze sektöründe net ihracatçı ülke iken, Türkmenistan ve Kazakistan ise net ithalatçı ülke konumundadır. Grubel-Lloyd indeks sonuçlarına göre ise Orta Asya ülkelerinin meyve sektöründe endüstri-içi ticaret seviyesinin düşük olduğu belirlenmiştir. Sebze sektöründe ise Kırgızistan hariç diğer bütün ülkelerin endüstri-içi ticaret seviyesinin düşük olduğu görülmüştür.

Orta Asya ülkeleri yaş meyve ve sebze dışsatımını arttırma ve pazarını genişletme şansına sahiptir. Söz konusu ülkelerin dünya yaş meyve ve sebze pazarındaki payını arttırabilmeleri için uluslararası pazarlarda talep edilen ürünlerin üretilerek piyasaya arz edilmesi gerekmektedir. Bununla birlikte, dış ticareti koruyabilmek amacıyla, tarımsal girdilerin kullanımı gelişmiş ülkeler standartlarında, çok bilinçli ve kontrollü yapılmalıdır. Bu konuda üreticilerin bilgilendirilmesi için tüm paydaşların aktif rol üstlenmesi gerekmektedir. Yaş meyve ve sebze ürünleri dışsatımının arttırılması için ihracata yönelik üretim teşvik edilmelidir. $\mathrm{Bu}$ bağlamda devlet ve özel sektör işbirliğini artıracak devlet politikalarının uygulanması gerekmektedir.

\section{Kaynakça}

Agwu, N.M., Nwankwo, E.E. ve Anyanwu, C.I. (2014). Determinants of Agricultural Labour Participation Among Youths in Abia State, Nigeria. International Journal of Food and Agricultural Economics, 2 (1), 157-164.

Aktan, C.C. ve Vural, Y.İ. (2004). Rekabet Gücü ve Rekabet Stratejileri, TİSK Yayını, Ankara.

Amighini, A. 2005. China in the International Fragmentation of Production: Evidence from the ICT Industry. The European Journal of Comparative Economics, 2 (2), 203-219

Bakhshinejad, M. ve Hassanzadeh, A. (2012). Comparative Advantage of Selected Agriculture Products in Iran: a Revealed Comparative Advantage Assessment. Agricultura Tropica et Subtropica, 45 (1), 28-31.

Bashimov, G. (2015). Özbekistan Pamuk Sektörünün Rekabet Gücünün Belirlenmesi. Türk Tarım ve Doğa Bilimleri Dergisi, 2 (1), 99-104.

Bashimov, G. 2016. Türkiye'nin Domates İhracat Performans1 ve Rekabet Gücü. Alınteri Zirai Bilimler Dergisi, 31 (2), 1-8.

Bielik, P. ve Qineti, A. (2010). The Position of Czech and Slovak Agro-Food Trade in the European Markets. Delhi Business Review, 11 (2), 1-10. 
Yalova Sosyal Bilimler Dergisi

Çiçek, R. ve Bashimov, G. (2016). Orta Asya'nın Pamuk Ticaretindeki Karşılaştırmalı Üstünlügünün Belirlenmesi. Uluslararası Yönetim İktisat ve Isşletme Dergisi, 12 (28), 1-14.

Çivi, E. (2001), Rekabet Gücü: Literatür Çalışması. Celal Bayar Üniversitesi İ.I.B.F. Yönetim ve Ekonomi Dergisi, 8 (2), 22-38.

Doğan, A. (2009). Yoksullar Lehine Büyümede Tarımın Rolü: Sahra-Altı Afrika Örneği. KMÜ I.I. B.F. Dergisi, 11 (16), 21-38.

Doğan, Z., Arslan, S. ve Berkman, A.N. (2015). Türkiye'de Tarım Sektörünün İktisadi Gelişimi ve Sorunları: Tarihsel Bir Bakış. Niğde Üniversitesi İ.̇.B.F, 8 (1), 29-41.

Erkan, B., Arpacı, B., Yaralı, F. ve Güvenç, İ. (2015). Türkiye'nin Sebze İhracatında Karşıllaştırmalı Üstünlükleri. KSÜ Doğa Bilimleri Dergisi, 18 (4), 70-76.

Erlat, G. ve Erlat, H. (2004). Türkiye'nin Orta Doğu Ülkeleri ile Olan Ticareti, 1990-2002, içinde GAP Bölgesinde Dış Ticaret ve Tarım, (Ed.: E. Uygur ve İ. Civcir), Ankara: TEK Yayını.

Fertö, I. ve Hubbard, L.J. (2003). Revealed Comparative Advantage and Competitiveness in Hungarian Agri-Food Sectors. The World Economy, 26 (2), 247-259.

Fertö, I. ve Bojnec, S. (2007). Comparative Advantages in Agro-food Trade of Hungary, Croatia and Slovenia with the European Union, IAMO Discussion Paper No: 106, Germany.

Gorton, M., Davidova, S. ve Ratinger, T. (2000). The Competitiveness of Agriculture in Bulgaria and the Czech Republic vis-a-vis the European Union (CEEC and EU Agricultural Competitiveness). Comparative Economic Studies, XLII (1), 59-86.

Hazners, J. ve Jirgena, H. (2013). Intra-Industry Trade in Latvian Agricultural Commodities and Food Products, International Conference on Economics and Business Administration, 16-19 July, Greece.

Hinloopen, J. ve Marrewijk, C.V. (2001). On the Empirical Distribution of the Balassa Index. Review of World Economics, 137 (1), 1-35.

Intracen. (2017). International Trade Statistics, http://www.intracen.org/itc/market-infotools/tradestatistics/ (Erişim: 12.03.2017).

Ishchukova, N. ve Smutka, L. (2013). Revealed Comparative Advantage of Russian Agricultural Exports. Acta Univ. Agric. Silvic. Mendelianae Brun. 61 (4), 941-952.

Kagochi, J.M. (2007). Evaluating the Competitiveness of US Agricultural Market Commodities, PhD Dissertation, Auburn University, Auburn, Alabama.

Kanaka, S. ve Chinadurai, M. (2012). A Study of Comparative Advantage of Indian Agricultural Exports. Journal of Management and Science, 2 (3), 1-9.

Kaya, P. ve Erdoğan Aktan, H. (2011).Türk Tarım Sektörü Verimliliğinin Parametrik Olmayan Bir Yöntemle Analizi. Uluslararası Alanya İşletme Fakültesi Dergisi, 3 (1), 261-282.

Kelleci, S. (2009). Avrupa Birliği’ne Giriş Sürecinde Türkiye’nin Rekabet Gücü: Karş1laştırmalı Üstünlükler Modeline Göre Sektörel Bir Analiz, Doktora Tezi, Adnan Menderes Üniversitesi, Sosyal Bilimler Enstitüsü, Aydın.

Kırankabeş, M.C. (2006). Küresel Rekabet Gücü Boyutunda AB Ülkeleri ile Türkiye'nin Karşılaştırmalı Analizi. Dumlupınar Üniversitesi Sosyal Bilimler Dergisi, 16, 231-254.

Leitão, N.C. ve Faustino, H.C. (2008).Intra-Industry Trade in the Food Processing Sector: the Portuguese Case. Journal of Global Business and Technology, 4 (1), 49-58.

Levkovych, I. (2008). Competitiveness of Cotton and Wheat Production and Processing in Central Asia, içinde Agri-food Business: Global Challenges-Innovative Solutions, (Ed.: Glauben, T., Hanf, J.H., Kopsidis, M., Pienadz, A. ve Reinsberg, K.), IAMO, Vol. 46, 133-150.

Mushanyuri, B.E. ve Mzumara, M. (2013). An Assessment of Comparative Advantage of Mauritius. European Journal of Sustainable Development, 2 (3), 35-42. 
Yalova Sosyal Bilimler Dergisi

Özçalık, M. ve Okur, A. 2013. Türk Tekstil ve Hazır Giyim Sektörlerinin Gümrük Birliği Sonrası AB-15 ülkeleri Karşısındaki Rekabet Gücü. Celal Bayar Üniversitesi Sosyal Bilimler Dergisi, 11 (1), 205-223

Özertan, G. (2013). Türkiye Tarım Sektöründe Yapısal Dönüşüm ve Teknoloji Kullanımının Rolü, http://www.econ.boun.edu.tr/public_html/RePEc/pdf/201301.pdf (Erişim: 20.01.2017).

Peker, A.E. (2015). Türkiye Hububat ve Baklagil Alt Sektörünün Avrupa Birliği Pazarı Karşısındaki Rekabet Gücü. Kahramanmaraş Sütçü İmam Üniversitesi İktisadi ve İdari Bilimler Fakültesi Dergisi, 5 (2), 1-20.

Peyrouse, S. (2009). The Multiple Paradoxes of the Agriculture Issue in Central Asia, Eucam Working Paper: 6.

Saraçoğlu, B. ve Köse, N. (2000). Bazı Gıda Sanayilerinin Uluslararası Rekabet Gücü: Makarna, Bisküvi ve Un Sanayi, TEAE Yayın No: 39, Ankara.

Sarker, R. ve Ratnasena, S. (2014). Revealed Comparative Advantage and Half a Century Competitiveness of Canadian Agriculture: A Case Study of Wheat, Beef and Pork Sectors, CATPRN Working Paper 2014-01.

Seyidoğlu, H. (2015). Uluslararası İktisat: Teori, Politika ve Uygulama, Geliştirilmiş 20. Baskı, Güzem Can Yayınları, İstanbul.

Yılmaz, Ş.K. (2014). Dış Ticaret Kuramlarının Evrimi, 3. Baskı, Efil Yayınevi, Ankara. 